\title{
BELAJAR BERSAMA ALAM SEBAGAI BENTUK PENERAPAN EKOLITERASI PADA SEKOLAH ALAM
}

\section{LEARNING WITH NATURE AS A FORM OF APPLICATION OF ECOLITERATION IN NATURE'S SCHOOL}

\author{
Annisa Rachmawati ${ }^{1 *}$, Minsih ${ }^{2}$ \\ ${ }^{12}$ Pendidikan Guru Sekolah Dasar Universitas Mubammadiyah Surakarta \\ 1*rahmaannisa495@gmail.com \\ 2min139@ums.ac.id
}

DOI: $10.35438 /$ cendekiawan.v3i2.216

Article Info

Historical Articles Submitted: 2021-05-18

Revised: $2021-12-17$

Issued: 2021-12-30

Keywords: Learning with Nature, eco-literacy, School of Nature
Abstract
The objectives of this research are: 1) Explaining the stages of learning. 2) Explaining the stages of Learning with Nature as a form of implementing eco. 3) Explaining the role of teachers in the implementation of Learning Together with. 4) Explaining the obstacles to implementing Learning with Nature. The method in this study uses a qualitative way. And data collection techniques using interviews and documentation. Based on the research, the results obtained are a) The stages of the learning process carried out at SD Mubammadiyah Alam Surya Mentari Surakarta starting from the Planning Stage, Implementation Stage, Evaluation Stage, and Follow Up Stage. b) Stages of Learning begins with the planning stage. Second, the implementation stage, where students directly plunge into nature. The third is the evaluation stage, and the fourth is the follow-up stage. c) The role of the teacher in the implementation of Learning Together with Nature is one of them as a role model, namely the teacher provides suitable role models and morals d) Obstacles in the implementation of Learning with Nature as a form of implementing ecoliteracy in nature schools, one of which is the weather factor and the lack of natural laboratories in the scope school.
Kata kunci: Belajar Bersama Alam, Ekoliterasi, Sekolah Alam

\section{Abstrak}

Tujuan dilakukan penelitian ini adalah: 1) Menjelaskan tahapan pembelajaran di SD Muhammadiyah Alam Surya Mentari Surakarta. 2) Menjelaskan tahapan Belajar Bersama Alam sebagai bentuk penerapan ekoliterasi di SD Muhammadiyah Alam Surya Mentari Surakarta. 3) Menjelaskan peran guru dalam pelaksanaan Belajar Bersama Alam sebagai bentuk penerapan ekoliterasi di SD Muhammadiyah Alam Surya Mentari Surakarta. 4) Menjelaskan kendala pelaksanaan Belajar Bersama Alam sebagai bentuk penerapan ekoliterasi di SD Muhammadiyah Alam Surya Mentari Surakarta. Metode di dalam penelitian ini menggunakan metode kualitatif. Dan teknik pengumpulan data menggunakan metode wawancara dan dokumentasi. Berdasarkan dari peneliatian yang sudah dilakukan diperoleh hasil: a) Tahapan proses pembelajaran yang dilakukan di SD Muhammadiyah Alam Surya Mentari Surakarta dimulai dari Tahap Perencanaan, Tahap Pelaksanaan, Tahap Evaluasi, dan Tahap Tindak Lanjut. b) Tahapan Belajar diawali dari tahap perencanaan. Kedua, tahap pelaksanaan yaitu peserta didik langsung terjun ke alam secara langsung. Ketiga, tahap evaluasi, dan keempat yaitu tahap tindak lanjut. c) Peran guru dalam pelaksanaan Belajar Bersama Alam salah satunya sebagai rolle model, yaitu guru memberikan suri tauladan dan akhlaq yang baik d) Kendala dalam pelaksanaan Belajar Bersama Alam sebagai bentuk penerapan ekoliterasi di sekolah alam yaitu salah satunya faktor cuaca dan minimnya laboratorium alam di lingkup sekolah. 
Annisa Rachmawati, Minsih/Cendekiawan VOL 2 (No. 1) (2021)

\section{PENDAHULUAN}

Pendidikan saat ini terlihat jelas bahwa hanya mengutamakan atau menekankan pencapaian kognitif saja, dan hal ini dirasa tidaklah cukup. Selama ini pendidikan hanya dilihat dari skor atau nilai peserta didik, apakah sudah bagus atau tidak pada saat ulangan atau nilai-nilai harian peserta didik, sehingga pola yang ditanamkan pada anak hanya berpusar pada bagaimana cara memperoleh nilai yang baik agar mampu bersaing dengan temannya saat di sekolah. hal ini sesuai pendapat (Ainiyah Nur, 2013) bahwa selama ini proses pembelajaran yang terjadi hanya menitik beratkan pada kemampuan kognitif anak sehingga ranah pendidikan karakter yang tercantum dalam tujuan pendidikan nasional tersebut hanya sedikit atau tidak tersentuh sama sekali. Dunia pendidikan saat ini tentunya membutuhkan cara yang mampu menumbuhkan rasa peduli terhadap lingkungan sekitar sehingga tidak hanya menekankan pada pencapaian kognitif peserta didik saja. Terkait hal ini, lingkungan merupakan tempat semua makhluk hidup berdampingan. Di dalamnya terdapat komponen biotik dan abiotik yang saling mempengaruhi. Bila salah satu diantara komponen tersebut rusak, maka lingkungan makhluk hidup didalamnya akan terpengaruh atau bahkan musnah, begitulah hukum alam terjadi oleh Rusmana \& Akbar (2017: 2).Salah satu alasan mengapa calon guru didorong untuk mengembangkan hubungan itu adalah bahwa semua tindakan manusia berdampak dan tergantung pada beberapa kegiatan atau interaksi yang dilakukan dalam kehidupan sehari-hari, dan hal ini sangat penting diajarkan kepada peserta didik atau anak-anak sejak dini untuk membangun kesadaran pentingnya menjaga lingkungan.

Pendidikan yang menanamkan tentang rasa kepedulian terhadap lingkungan kepada peserta didik di era saat ini sangat minim, hal ini terlihat jelas bahwa pencapaian kognitif menjadi point utama untuk mengukur keberhasilan belajar. Berkaitan dengan hal tersebut menyebabkan peserta didik banyak yang kurang memahami pentingnya menjaga lingkungan sekitar, terbukti dari kurangnya kesadaran untuk membuang sampah pada tempatnya. Masih sering dijumpai lingkungan sekolah yang masih banyak terdapat sampah-sampah bungkus makanan yang dibuang sembarangan dan tidak dibuang ke tempat sampah, dan banyak peserta didik yang masih kurang kesadaran untuk saling mengingatkan untuk tidak membuang sampah sembarangan. Masalah terhadap lingkungan ini merupakan tanggung jawab bersama. Terkait masalah tersebut, maka diperlukan suatu langkah nyata dalam menyelesaikan masalah lingkungan, salah satu upaya yang harus dilakukan yaitu memasukkannya ke dalam pembelajaran di tingkat sekolah dasar pada sekolah alam.

Sekolah Alam, sekolah yang menggunakan alam semula jadi sebagai tempat pembelajaran, sekolah alam, pelajar belajar di luar rumah, di mana subjek perkara itu dipelajari bukan saja secara teori tetapi diamalkan secara langsung. Konsep ini membawa pelajar lebih dekat jadi menjadikan aktifitas pembelajaran lebih menyenangkan oleh Siregar \& Quimbo (2016: 71). Sekolah alam adalah sekolah yang unik lingkungan yang serba natural, media pembelajaran berbasis alam dan penuh kebebasan, bebas dalam menentukan pakaiannya sendiri, cara belajar, mencapai kesepakatan dalam peraturan sekolah, serta bebas berekplorasi dengan lingkungan yang ada. Selain itu proses perkembangan disesuaikan dengan kapasitas perkembangan anak, sehingga pembentukan anak untuk menjadi dirinya sendiri adalah sesuatu yang terpenting. Sejak awal anak-anak diperkenalkan dengan lingkungan yang nyata belajar di alam terbuka dan penuh dengan fun learning oleh Hidayat (2019: 48). Terkait hal ini, maka bisa dikatakan bahwa sekolah alam adalah sekolah yang menjadikan alam sebagai sumber dan tempat belajar, serta konsep belajar yang berbasis aktifitas secara langsung. Sekolah alam membebaskan peserta didik untuk bereksplorasi dan mengenal alam atau lingkungan sekitar, sehingga diharapkan mereka memiliki rasa peduli terhadap lingkungan.

Memiliki rasa peduli terhadap lingkungan erat kaitannya dengan ekoliterasi. Dalam hal ini, Ecoliteracy atau sering disebut dengan kecerdasan ekologi adalah kemampuan kita untuk dapat beradaptasi dengan ekologis tempat kita berada oleh Rusmana \& Akbar (2017: 2). Ecoliteracy adalah 
kependekan dari ekologi literasi, juga dikenal sebagai literasi ekologis, literasi lingkungan, keaksaraan ekologis dan keaksaraan lingkungan. Dalam istilah sederhana Ecoliteracy dapat didefinisikan sebagai pemahaman, memahami dan mempraktikkan nilai-nilai ekologis yang berguna dalam mengatasi masalah lingkungan. Awalnya ekoliterasi lebih dikenal dengan kesadaran ekologis, atau kesadaran ekologis. Dengan menggunakan kata ecoliteracy, artinya tidak hanya meningkatkan kesadaran untuk peduli terhadap lingkungan, tetapi juga memahami cara kerja prinsip-prinsip ekologis dalam kehidupan bersama yang berkelanjutan di planet bumi ini oleh Putri et al. (2019: 255-264). Membangun ekoliterasi sangat penting dalam sekolah dasar karena tinggi kecerdasan ekologis peserta didik akan menumbuhkan kesadaran bahwa alam seharusnya dilestarikan oleh Noviana et al. (2018: 69-70). Beberapa penjelasan tersebut, dapat di ambil kesimpulan bahwa ekoliterasi merupakan suatu bentuk kesadaran untuk peduli terhadap lingkungan, kesadaran untuk melestarikan lingkungan alam sekitar.

Menindaklanjuti hal tersebut, generasi muda sejak dini harus diperkenalkan dengan kesadaran terhadap lingkungan, guna menciptakan masyarakat yang peduli terhadap lingkungan. Metode pembelajaran yang berlangsung di alam akan membuat peserta didik lebih aktif dan tidak mudah bosan dalam mengikuti pembelajaran oleh Sulthan (2019: 323). Maka dari itu dibuat suatu terobosan yaitu Belajar Bersama Alam, dimana di dalam Belajar Bersama Alam peserta didik akan lebih sering berinteraksi dengan lingkungan alam sekitar. Pembelajaran berbasis alam menjadikan pengetahuan dan pengalaman yang diperoleh oleh siswa lebih dekat dan mensyukuri ciptaan Allah, memiliki perilaku atau sikap mental yang kuat, ia menjadi penyayang tumbuhan, binatang dan juga alam sekitarnya, selain itu siswa juga memiliki sikap yang baik dan ramah terhadap alam oleh (Sunanik, 2018: 81-110)

\section{METODE}

Penelitian ini menggunakan jenis penelitian kualitatif. Menurut Anggito \& Setiawan (2018: 11) penelitian kualitatif (Qualitative Research) yaitu penelitian mendeskripsikan suatu objek, fenomena, atau setting sosial yang akan di tayangkan dalam tulisan yang bersifat naratif. Arti dalam penulisannya data dan fakta yang di himpun berbentuk kata atau gambar daripada angka. Dalam penelitian ini berisi deskripsi data dan fakta terkait topic skripsi yaitu Belajar Bersama Alam Sebagai Bentuk Penerapan Ekoliterasi.

Peneliti bertujuan untuk mengulas pelaksanaan belajar bersama alam sebagai bentuk penerapan ekoliterasi di SD Muhammadiyah Alam Surya Mentari Surakarta secara naratif. Metode yang digunakan di dalam penelitian ini yaitu menggunakan metode kualitatif. Pada judul penelitian ini yaitu Belajar Bersama Alam Sebagai Bentuk Penerapan Ekoliterasi Pada Sekolah Alam, peneliti bertujuan menggali dan mencari pengertian mendalam fakta atau ralita tentang pelaksanaan Belajar Bersama Alam Sebagai Bentuk Penerapan Ekoliterasi Pada Sekolah Alam.

Teknik yang digunakan oleh peneliti dalam pengambilan data yaitu melalui wawancara dan dokumentasi. Langkah yang diambil peneliti yang pertama yaitu menyususn instrument wawancara terlebih dahulu yang akan digunakan untuk menggali informasi dari narasumber yang dituju. Setelah itu, peneliti menyusun data mentah yang diperoleh dari proses wawancara tersebut, kemudian diolah dan menyajikan menjadi naskah penelitian. Selanjutnya untuk mendukung hasil penelitian yang telah dilakukan, peneliti mencari data atau fakta berupa dokumen atau gambar yang akan dimasukkan ke dalam bentuk dokumentasi. Sehingga data yang diperoleh lebih kuat dengan disertai hasil dokumentasi yang dikumpulakn oleh peneliti. Menurut Raco. J. R, (2010: 1-4) metode kualitatif adalah mencari pengertian yang mendalam tentang suatu gejala, fakta, atau realita. Fakta, realita, masalah, gejala serta peristiwa hanya dapat dipahami bila peneliti menelusurinya secara mendalam dan tidak hanya terbatas pada pandangan dipermukaan saja. 
Pelaksanaan wawancara tersebut bertujuan untuk memperoleh data dari narasumber, sehingga peneliti mendapatkan sumber data yang dapat dipercaya. Sedangkan data dari dokumentasi digunakan sebagai pendukung hasil wawancara yang telah dilakukan antara peneliti dan narasumber. Menurut Fatiihudin \& Holisin (2011: 26), wawancara (Interview) merupakan salah satu teknik pengumpulan data dengan cara mengadakan tanya jawab, baik secara langsung maupun tidak langsung bertatap muka (face to face) dengan sumber data (responden). Wawancara langsung adalah tanya jawab langsung dengan orang yang menjadi satuan pengamatan dan dilakukan tanpa perantara. Responden sebagai sumber data. Sedangkan wawancara tidak langsung dilakukan terhadap orang yang dimintai keterangan tentang orang lain oleh. Dalam penelitian ini wawancara akan dilakukan kepada narasumber dari pihak terkait, yaitu: Kepala sekolah, guru. Dokumentasi dilakukan untuk mengambil data berupa surat-surat, catatan harian, laporan, cenderamata, artefak, foto, dan sebagainya. Sifat utama data ini tak terbatas pada ruang dan waktu sehingga memberi peluang kepada peneliti untuk mengetahui hal-hal yang pernah terjadi di waktu silam oleh Rahmat (2009: 1-8). Dalam penelitian ini dokumentasi yang di ambil yaitu meliputi di antaranya fasilitas sekolah terkait ruang dan fasilitas terkait sumber belajar.

\section{HASIL PENELITIAN}

Berdasarkan hasil wawancara yang dilakukan peneliti terhadap narasumber di SD Muhammadiyah Alam Surya Mentari Surakarta, diperoleh data sebagai berikut:

\section{Pemahaman terkait Tahapan Pembelajaran di SD Muhammadiyah Alam Surya Mentari Surakarta}

Tahapan proses pembelajaran yang dilakukan di SD Muhammadiyah Alam Surya Mentari Surakarta, yaitu: Tahap Perencanaan yaitu yang awalnya adalah pemetaan KI-KD ke dalam spyder web dan tema, kemudian kita buat weekly plan/rencana belajar selama satu pekan. Dan di dalam tahap ini guru menyusun Rencana Pelaksanaan Pembelajaran (RPP) yang mencerminkan pembelajaran berpusat pada siswa. Tahap Pelaksanaan yaitu melaksanaan pembelajaran sesuai dengan Rencana Pelaksanaan Pembelajaran (RPP) yang telah disusun. Tahap Evaluasi yaitu dilakukan selama proses pembelajaran. Tahap Tindak Lanjut yaitu untuk mengembangkan proses pembelajaran yang lebih baik. 
Tabel 1. Hasil wawancara terhadap narasumber di SD Muhammadiyah Alam Surya Mentari Surakarta

\begin{tabular}{llll}
\hline \multicolumn{1}{c}{ Indikator } & \multicolumn{2}{c}{ Hasil Wawancara Analisis } \\
\hline Indikator 1: & Tahapan proses pembelajaran yang dilakukan di Dalam tahap pembelajaran \\
Tahapan & SD Muhammadiyah Alam Surya Mentari di SD Muhammadiyah \\
proses & Surakarta, yaitu: Tahap Perencanaan yaitu yang Alam Surya Mentari \\
pembelajaran & awalnya adalah pemetaan KI-KD ke dalam spyder Surakarta sama seperti \\
SD & web dan tema, kemudian kita buat weekly tahapan pembelajaran pada \\
Muhammadiy & plan/rencana belajar selama satu pekan. Dan di umumnya yaitu di mulai \\
ah Alam & dalam tahap ini guru menyusun Rencana dari Tahap Perencanaan, \\
Surya Mentari & Pelaksanaan Pembelajaran (RPP) yang Tahap Pelaksanaan, Tahap, \\
Surakarta & mencerminkan pembelajaran berpusat pada siswa. dan Tahap Tindak Lanjut. \\
& Tahap Pelaksanaan yaitu melaksanaan & \\
& pembelajaran sesuai dengan Rencana Pelaksanaan & \\
& Pembelajaran (RPP) yang telah disusun. Tahap & \\
& Evaluasi yaitu dilakukan selama proses & \\
pembelajaran. Tahap Tindak Lanjut yaitu untuk & \\
& mengembangkan proses pembelajaran yang lebih & \\
baik.
\end{tabular}

Berdasarkan penjelasan tabel 1 dapat diambil kesimpulan bahwa tahapan proses pembelajaran dimulai dari tahap perencanaan dengan pemetaan SK/KD, tahap pelaksanaan kegiatan pembelajaran sesuai RPP yang telah disusun, dan tahap evaluasi selama proses pembelajaran dan pemberian tugastugas, serta tindak lanjut untuk mengembangkan pembelajaran yang lebih baik lagi kedepannya.

Tahapan pelaksanaan Belajar Bersama Alam (BBA) sebagai penerapan ekoliterasi di SD Muhammadiyah Alam Surya Mentari Surakarta

Tahapan pelaksanaan Belajar Bersama Alam (BBA) sebagai penerapan ekoliterasi di SD Muhammadiyah Alam Surya Mentari Surakarta sudah sesuai dengan prinsip pembelajaran berbasis alam, tahapan pelaksanaannya dimulai dari: 1) Tahap Perencanaan yaitu yang awalnya adalah pemetaan KI-KD ke dalam spyder web dan tema, kemudian guru buat weekly plan/rencana belajar selama satu pekan. Dan di dalam tahap ini guru menyusun Rencana Pelaksanaan Pembelajaran (RPP) yang mencerminkan pembelajaran berpusat pada siswa. Selanjutnya, 2) Tahap Pelaksanaan yaitu melaksanakan pembelajaran sesuai dengan Rencana Pelaksanaan Pembelajaran (RPP) yang telah disusun. Di dalam tahap ini menentukan konsep pembelajaran dengan BBA, misalnya saja kegiatan/aktivitas yang sesuai dengan tema yang akan dipelajari, metode/strategi yang akan digunakan, dll), pelaksanaan (proses pembelajaran, nilai yang dibangun dalam pembelajaran, waktu pelaksanaan, tempat pelaksanaan, kegiatan unggulan, strategi dalam penyampaian pembelajaran, peran serta peserta didik, dll). Dalam tahap pelaksanaan ini, langkah Pertama, peserta didik langsung terjun ke lapangan (luar kelas), yang dimaksud disini yaitu terjun ke alam secara langsung. Kemudian mencari sumber belajar, yang dimaksud yaitu dari tujuan pembelajaran yang telah dibuat sebelumnya, peserta didik mencari sumber belajarnya langsung dari alam selama proses pembelajaran berlangsung. Selanjutnya bereksplorasi, artinya peserta didik dibiarkan untuk bereksplorasi dengan alam sekitar sesuai dengan materi yang diajarkan. Kemudian peserta didik menuliskan hasil dari eksplorasi alam sekitar yang sudah mereka lakukan. Setelah itu hasilnya dikumpulkan menjadi satu baru dianalisis satu-satu secara bersama-sama dengan guru. Kemudian, 3) Tahap Evaluasi yaitu dilakukan selama proses pembelajaran. Terakhir, 4) Tahap Tindak Lanjut yaitu untuk mengembangkan proses pembelajaran yang lebih baik. 
Pelaksanaan Belajar Bersama Alam untuk pembelajaran di luar IPA memiliki tahapan yang hampir sama, yaitu: 1) Perencanaan (yang awalnya adalah pemetaan KI-KD ke dalam spyder web dan tema, kemudian membuat weekly plan/rencana belajar selama satu pekan. 2) Menentukan konsep pembelajaran dengan BBA misalnya saja kegiatan/aktivitas yang sesuai dengan tema yang akan dipelajari, metode/strategi yang akan digunakan, dll), pelaksanaan (proses pembelajaran, nilai yang dibangun dalam pembelajaran, waktu pelaksanaan, tempat pelaksanaan, kegiatan unggulan, strategi dalam penyampaian pembelajaran, peran serta peserta didik, dll). 3) Evaluasi pembelajaran (hambatan dan solusi).

Tabel 2. Hasil wawancara terhadap narasumber di SD Muhammadiyah Alam Surya Mentari Surakarta

\begin{tabular}{|c|c|c|}
\hline Indikator & Hasil Wawancara & Hasil Analisis \\
\hline $\begin{array}{l}\text { Indikator 2: } \\
\text { Tahapan } \\
\text { pelaksanaan } \\
\text { Belajar } \\
\text { Bersama Alam } \\
\text { (BBA) sebagai } \\
\text { penerapan } \\
\text { ekoliterasi }\end{array}$ & $\begin{array}{l}\text { Tahapan Belajar Bersama Alam (BBA) di } \\
\text { SD Muhammadiyah Alam Surya Mentari } \\
\text { Surakarta yaitu: } \\
\text { 1).Tahap Perencanaan yaitu yang awalnya } \\
\text { adalah pemetaan KI-KD ke dalam spyder web } \\
\text { dan tema, kemudian membuat weekly } \\
\text { plan/rencana belajar selama satu pekan. } \\
\text { Tahap ini guru menyusun RPP } \\
\text { 2).Tahap Pelaksanaan yaitu melaksanaan } \\
\text { pembelajaran sesuai dengan Rencana } \\
\text { Pelaksanaan Pembelajaran (RPP). Di dalam } \\
\text { tahap ini menentukan konsep pembelajaran } \\
\text { dengan BBA. } \\
\text { 3).Tahap Evaluasi yaitu dilakukan selama } \\
\text { proses pembelajaran. } \\
\text { 4).Tahap Tindak Lanjut yaitu untuk } \\
\text { mengembangkan proses pembelajaran yang } \\
\text { lebih baik. }\end{array}$ & $\begin{array}{l}\text { Dalam tahap pelaksanaan, } \\
\text { langkah Pertama yaitu peserta } \\
\text { didik langsung terjun ke lapangan } \\
\text { (i yaitu terjun ke alam secara } \\
\text { langsung. Kemudian mencari } \\
\text { sumber belajar, yang dimaksud } \\
\text { yaitu mencari sumber belajarnya } \\
\text { langsung dari alam. Selanjutnya } \\
\text { bereksplorasi, artinya peserta } \\
\text { didik dibiarkan bereksplorasi } \\
\text { dengan alam sesuai materi yang } \\
\text { diajarkan. Kemudian peserta didik } \\
\text { menuliskan hasil dari eksplorasi } \\
\text { alam sekitar. Setelah itu hasilnya } \\
\text { di analisis satu-satu secara } \\
\text { bersama-sama dengan guru }\end{array}$ \\
\hline
\end{tabular}

Berdasarkan penjelasan tabel 2 dapat diambil kesimpulan bahwa tahapan pelaksanaan Belajar Bersama Alam (BBA) yang dilaksanakan di SD Muhammadiyah Alam Surya Mentari Surakarta yaitu dimulai dari tahap perencanaan yang dimana guru melakukan pemetaan KI-KD ke dalam spyder web dan tema, kemudian kita buat weekly plan/rencana belajar selama satu pekan. Dan di dalam tahap ini guru menyusun Rencana Pelaksanaan Pembelajaran (RPP), kemudian tahap pelaksanaan dimana guru melaksanaan pembelajaran sesuai dengan Rencana Pelaksanaan Pembelajaran (RPP) yang telah disusun. Di dalam tahap ini menentukan konsep pembelajaran dengan BBA, lalu tahap evaluasi yang dilakukan selama berlangsungnya proses pembelajaran, dan tahap tindak lanjut untuk mengembangkan pembelajaran yang lebih baik kedepannya.

Metode Belajar Bersama Alam (BBA) sebagai penerapan ekoliterasi di SD Muhammadiyah Alam Surya Mentari Surakarta

Guru dalam menyampaikan proses pembelajaran tentunya menggunakan metode yang berbedabeda disesuikan dengan materi yang akan disampaikan. Hal ini sesuai pendapat Aditya (2016: 165) bahwa Guru sebagai pendidik harus menguasai bermacam-macam metode mengajar. Hal itu dimaksudkan agar para guru dapat melakukan pendekatan yang tepat untuk diterapkan pada tingkat perkembangan intelektual siswa. Menurut Nasution (2017: 13) adanya metode yang tepat pada dasarnya bertujuan untuk meciptakan kondisi pembelajaran yang siswa dapat belajar secara aktif dan 
menyenangkan berdampak positif pada hasil belajar dan prestasi yang optimal, dengan penggunaan metode pembelajaran mempermudah proses kegiatan belajar mengajar.

Tabel 3. Hasil wawancara terhadap narasumber di SD Muhammadiyah Alam Surya Mentari Surakarta

\begin{tabular}{llll}
\hline \multicolumn{1}{c}{ Indikator } & \multicolumn{2}{c}{ Hasil Wawancara } \\
\hline Indikator 3: & Metode yang biasa digunakan guru di SD \\
Metode & Muhammadiyah Alam Surya Mentari proses pembelajaran tentunya \\
Belajar & Surakarta dalam menyampaikan proses menggunakan metode, dan guru \\
Bersama Alam & pembelajaran, yaitu: Ceramah, Studi lapangan dalam penggunaan metode \\
(BBA) sebagai & (Field Trip), Tanya jawab, Metode action pembelajaran disesuaikan \\
penerapan & learning, Metode Diskusi, Metode Projek, dengan materi yang akan \\
ekoliterasi & Metode Problem Solving, Eksperimen, disampaikan kepada peserta \\
& Observasi, Project Best Learning, Latihan. & didik. Ini juga tertera di dalam \\
& & RPP.
\end{tabular}

Metode yang biasa digunakan di SD Muhammadiyah Alam Surya Mentari Surakarta ketika menyampikan pembelajaran, diantaranya yaitu: 1) Ceramah, yaitu guru memberikan penjelasan terkait materi pembelajaran secara lisan terhadap peserta didik. 2) Studi lapangan (Field Trip), yaitu proses pembelajaran yang dilakukan secara outdoor, guru mengajak siswa keluar kelas dan memanfaatkan lingkungan sekitar untuk belajar. 3) Tanya jawab, yaitu guru memberikan pertanyaan terkait materi yang telah dipelajari, kemudian peserta didik menjawab pertanyaan yang telah diajukan oleh guru tersebut. 4) Metode Action learning yaitu belajar sambil berbuat, bertindak, dan bermain. 5) Metode Diskusi yaitu aktivitas pembelajaran dengan memberi peserta didik suatu permasalahan yang bisa berbentuk pertanyaan atau fakta, dan mengarahkan peserta didik untuk menyelesaikannya. 6) Metode Projek yaitu proses belajar yang disajikan bertitik tolak dari suatu masalah, lalu dipecahkan dari berbagai segi yang berhubungan. 7) Metode Problem Solving yaitu cara mengajar yang dilakukan dengan cara melatih peserta didik menghadapi berbagai masalah untuk dipecahkan sendiri atau secara bersama-sama. 8) Eksperimen yaitu suatu cara mengajar dimana siswa melakukan suatu percobaan tentang sesuatu hal. 9) Observasi yaitu mengamati, menyaksikan atau memperhatikan suatu peristiwa atau tindakan. 10) Project Best Learning yaitu metode pembelajaran yang menggunakan proyek atau kegiatan sebagai media dan untuk menggali informasi yang mendalam terhadap suatu topik. 11) Latihan, yaitu siswa melakukan kegiatan-kegiatan latihan sesuai arahan dari guru, agar speserta didik memiliki keterampilan yang lebih baik. Berdasarkan penjelasan diatas dapat disimpulkan bahwa guru dalam menyampaikan pembelajaran menggunakan berbagai metode yang berbeda-beda, karena disesuaikan dengan materi yang akan diajarkan.

Kendala di dalam pelaksanaan Belajar Bersama Alam (BBA) sebagai penerapan ekoliterasi di SD Muhammadiyah Alam Surya Mentari Surakarta

Proses pembelajaran hanya di ruang lingkup sekolah maka dari itu laboratorium alam nya juga terbatas. Ada beberapa dari sumber daya alam yang di sekolah itu tidak bisa memenuhi dari tujuan pembelajaran yang akan kita capai. Selain kendala ruang lingkup laboratorium alam yang terbatas, kendala yang terkadang terjadi, contohnya: a) Terkadang dalam pembelajaran membutuhkan waktu yang lama, yang terkadang membuat mood anak-anak yang kurang. b) Minat/ ketertarikan peserta didik terhadap sesuatu atau belajar itu sendiri berbeda-beda. c) Faktor lingkungan alami: keadaan udara, cuaca, waktu, dan lain-lain.

Pelaksanaan Belajar Bersama Alam (BBA) dalam pembelajaran di luar pembelajaran IPA pasti ada, mungkin kendala terbesarnya adalah bagaimana memilih dan memilah mencocokkan sub 
materi apa dari mata pelajaran tertentu yang bisa kita masukkan dalam kegiatan pembelajaran itu. Selain kendala tersebut, kendala yang pada pelaksanaan BBA diluar pembelajaran IPA hampir sama dengan pelaksanaan BBA pada pembelajaran IPA, yaitu: 1) Terkadang dalam pembelajaran membutuhkan waktu yang lama, yang terkadang membuat mood anak-anak yang kurang. 2) Minat/ ketertarikan peserta didik terhadap sesuatu atau belajar itu sendiri berbeda-beda. 3) Faktor lingkungan alami: keadaan udara, cuaca, waktu, dll.

Tabel 4. Hasil wawancara terhadap narasumber di SD Muhammadiyah Alam Surya Mentari Surakarta

\begin{tabular}{llll}
\hline \multicolumn{1}{c}{ Indikator } & \multicolumn{1}{c}{ Hasil Wawancara } & Hasil Analisis \\
\hline Indikator 4: & Proses pembelajaran hanya di ruang lingkup & Kendala dalam proses \\
Kendala & di & sekolah maka dari itu laboratorium alam nya & pembelajaran yaitu keterbatasan \\
dalam & juga terbatas, ada beberapa dari sumber daya & ruang lingkup sumber belajar \\
pelaksanaan & alam yang di sekolah itu tidak bisa memenuhi & atau laboratorium alam yang \\
Belajar & dari tujuan pembelajaran yang akan kita capai. & tidak semua bisa tersedia di \\
Bersama Alam & Selain kendala ruang lingkup laboratorium lingkungan sekolah, selain itu \\
(BBA) sebagai & alam yang terbatas, kendala yang terkadang terkadang dalam pembelajaran \\
penerapan & ada, contohnya: Terkadang dalam membutuhkan waktu yang lama, \\
ekoliterasi & pembelajaran membutuhkan waktu yang lama, mood anak-anak yang kurang, \\
& yang terkadang membuat mood anak-anak yang & Minat/ ketertarikan peserta \\
& kurang, Minat/ ketertarikan peserta didik didik terhadap sesuatu atau \\
& terhadap sesuatu atau belajar itu sendiri belajar itu sendiri berbeda-beda, \\
& berbeda-beda, Faktor lingkungan alami: keadaan udara, cuaca, waktu.
\end{tabular}

Solusi terkait kendala di dalam pelaksanaan Belajar Bersama Alam (BBA) sebagai penerapan ekoliterasi di SD Muhammadiyah Alam Surya Mentari Surakarta

Solusi yang dilakukan setiap guru berbeda-beda untuk kendala pelaksanaan di luar pembelajaran IPA, karena mereka mempunyai kelebihan dan keahlian sendiri-sendiri, sehingga untuk mengatasi kendala yang ada, mungkin setiap guru punya solusi tersendiri. Kemudian, karena guru tidak bisa memasukkan semuanya, solusinya adalah guru hanya bisa memasukkan beberapa sub-sub materi atau KD tertentu dalam satu kegiatan pembelajaran dan apabila ingin mencapai seluruh tujuan pembelajaran maka hitungannya bukanlah perkegiatan pembelajaran tetapi lebih proyek tema itu. Jadi dapat diambil kesimpulan bahwa guru mempunyai solusi sendiri-sendiri terkait kendala yang dialami selama proses pembelajaran. Pendapat dari (Yuliani \& Supriyanto, 2019: 7) menjelaskan bahwa kepala sekolah harus sering melalukan pembinaan rutin, mengingatkan secara terus-menerus. Kepala sekolah juga melakukan evaluasi terhadap guru. 
Tabel 5. Hasil wawancara terhadap narasumber di SD Muhammadiyah Alam Surya Mentari Surakarta.

\begin{tabular}{|c|c|c|}
\hline Indikator & Hasil Wawancara & Hasil Analisis \\
\hline $\begin{array}{l}\text { Indikator 5: } \\
\text { Solusi terkait } \\
\text { kendala di } \\
\text { dalam } \\
\text { pelaksanaan } \\
\text { Belajar } \\
\text { Bersama Alam } \\
\text { (BBA) sebagai } \\
\text { penerapan } \\
\text { ekoliterasi }\end{array}$ & $\begin{array}{l}\text { Solusi mengatasi mood peserta didik, biasanya } \\
\text { guru selalu memberikan semangat dan sesuatu } \\
\text { yang membuat anak didik itu tertarik untuk } \\
\text { mempelajari lebih jauh dan lebih dalam. } \\
\text { Kemudian untuk kendala terkait keterbatasan } \\
\text { laboratorium alam yang tersedia di ruang lingkup } \\
\text { sekolah, solusinya adalah guru akan } \\
\text { menggunakan metode lain, misalkan } \\
\text { menampilakan film atau video yang berkaitan } \\
\text { dengan materi yang akan guru sampaikan atau } \\
\text { meminta anak-anak membawa sesuatu yang akan } \\
\text { di kaji lebih ulang bersama yang dimana di } \\
\text { sekolah itu tidak ada. }\end{array}$ & $\begin{array}{l}\text { Keterbatasan sumber } \\
\text { belajar atau laboratorium } \\
\text { alam yang ada di sekolah } \\
\text { tidak membatasi kreatifitas } \\
\text { guru dalam penyampaian } \\
\text { proses pembelajaran, solusi } \\
\text { yang digunakan guru dalam } \\
\text { penyampaian pembelajaran } \\
\text { bisa menggunakan gambar, } \\
\text { video, dll. }\end{array}$ \\
\hline
\end{tabular}

Berdasarkan penjelasan tabel 5 dapat diambil kesimpulan bahwa guru mempunyai solusi sendiri terkait kendala yang dialami selama melakukan menyampaikan pembelajaran terhadap peserta didik, karena setiap guru memiliki kesulitan yang berbeda-beda. Maka dalam menyikapi kesulitan tersebut guru memiliki solusi berbeda disesuaikan kendala yang dihadapi.

Peran guru di dalam pelaksanaan Belajar Bersama Alam (BBA) sebagai penerapan ekoliterasi di SD Muhammadiyah Alam Surya Mentari Surakarta

Guru memiliki beberapa peran di dalam pelaksanaan Belajar Bersama Alam (BBA), diantaranya guru berperan sebagai: a) Guru sebagai rolle model dalam pembelajaran yaitu guru memberikan suri tauladan dan akhlaq yang baik kepada anak didiknya. b) Guru berperan sebagai pengarah maksudnya yaitu guru mampu mengarahkan siswa apabila di dalam mengikuti proses pembelajaran siswa ada yang kesulitan. c) Guru sebagai pembimbing maksudnya yaitu guru harus bisa membimbing para siswanya dengan baik ketika mengikuti proses pembelajaran sehingga bisa tercapai tujuan pembelajaran. d) Guru sebagai motivator maksudnya yaitu guru harus mampu membangkitkan semangat siswa dalam belajar atau mengikuti proses pembelajaran di sekolah. e) Guru sebagai fasilitator yang artinya membiarkan anak bereksplorasi sampai mereka bingung dan timbul pertanyaan, dan peran guru akan mejelaskan apa yang mereka bingungkan dan mereka pertanyakan. 
Tabel 6. Hasil wawancara terhadap narasumber di SD Muhammadiyah Alam Surya Mentari Surakarta.

\begin{tabular}{lllll}
\hline \multicolumn{2}{c}{ Indikator } & \multicolumn{2}{c}{ Hasil Wawancara } & Hasil Analisis \\
\hline Indikator 6: Peran guru di & Guru memiliki beberapa & Peran guru dalam keberhasilan \\
dalam pelaksanaan Belajar & peran di dalam proses pembelajaran sangatlah \\
Bersama Alam (BBA) sebagai & pelaksanaan & Belajar penting. Peran guru dalam proses \\
penerapan ekoliterasi & Bersama Alam (BBA), pembelajaran diantaranya yaitu guru \\
& diantaranya yaitu: Guru sebagai rolle model, pembimbing, \\
& sebagai rolle model, Guru pengarah, fasilitator, dll. \\
& sebagai pengarah, Guru \\
& sebagai pembimbing, \\
& Guru sebagai motivator, \\
& Guru sebagai fasilitator.
\end{tabular}

Berdasarkan penjelasan tabel 6 dapat dipahami bahwa peran guru di dalam pelaksanaan Belajar Bersama Alam (BBA) itu tentunya sangat penting, karena guru yang akan menyampaikan materi terhadap peserta didik. Guru memiliki beberapa peran penting diantaranya yaitu guru sebagai rolle model, guru sebagai motivator, guru sebagai fasilitator, guru sebagai pembimbing, guru sebagai pengarah.

\section{PEMBAHASAN}

Pemahaman terkait Tahapan Pembelajaran di SD Muhammadiyah Alam Surya Mentari Surakarta

Tahapan pembelajaran seperti pendapat dari (M. Khusniati, 2012: 2016-207) bahwa proses pembelajaran dimulai dari tahap perencanaan, tahap pelaksanaan dan tahap evaluasi pembelajaran, yaitu: Tahap Perencanaan, pada tahap perencanaan dilakukan analisis SK/KD, pengembangan silabus, penyusunan RPP, dan penyiapan bahan ajar.Analisis SK/KD dilakukan untuk mengidentifikasi nilai-nilai karakter yang relevan/sesuai secara substansi. Tahap Pelaksanaan, kegiatan pembelajaran dari tahapan kegiatan pendahuluan, inti, dan penutup, dipilih dan dilaksanakan agar peserta didik mempraktikkan nilai-nilai karakter yang ditargetkan. Selain itu, perilaku guru sepanjang proses pem-belajaran harus merupakan model pelaksanaan nilai-nilai bagi peserta didik. Tahap Evaluasi Pembelajaran, pemberian tugas-tugas penguatan (terutama pengayaan) diberikan untuk memfasilitasi peserta didik belajar lebih lanjut tentang kompetensi yang sudah dipelajari dan internalisasi nilai lebih lanjut. Tugas-tugas tersebut antara lain dapat berupa PR yang dikerjakan secara individu dan/atau kelom-pok baik yang dapat diselesaikan dalam jangka waktu yang singkat ataupun panjang (lama) yang berupa proyek. Tugas-tugas tersebut selain dapat meningkatkan penguasaan yang ditargetkan, juga menanamkan nilai-nilai.

Tahapan pelaksanaan Belajar Bersama Alam (BBA) sebagai penerapan ekoliterasi di SD Muhammadiyah Alam Surya Mentari Surakarta

Prinsip pembelajaran berbasis alam seperti pernyataan menurut (Kamelia et al., 2020: 42-47) proses pembelajaran berbasis alam perlu memperhatikan sejumlah prinsip yang mendasarinya, diantaranya adalah: Berpusat pada perkembangan anak dan optimalisasi perkembangan keberhasilan proses pembelajaran berbasis alam terletak pada peningkatan optimalisasi seluruh potensi perkembangan anak dengan menjadi lingkungan alam sebagai sumber belajar yang utama, Membangun kemandirian anak, Belajar dari lingkungan alam sekitar, Belajar dan bermain dari lingkungan sekitar, Memanfaatkan sumber belajar yang mudah dan murah, Pembelajaran menggunakan pendekatan tematik, Membangun kebiasaan berpikir ilmiah sejak usia dini, 
Pembelajaran inspiratif, menarik, kreatif dan inovatif anak. Menurut pendapat (Ritonga, 2020: 61-62) menyatakan bahwa, Belajar Bersam Alam (BBA) bearti menjadikan alam semesta sebagai hands-on, bukan belajar lewat buku dahulu, namun pertama kali harus dimulai dengan mengalami interaksi langsung dengan makhluk Tuhan bernama alam semesta. Tanaman, tumbuhan, hewan, cuaca, gunung, dll. Belajar dengan buku pasti berbeda sekali dengan belajar daun dengan menyanyanginnya. Apalagi jika dimulai dengan menanamnya, menyanyanginya, merawatnya, mempelajarinya, mengembangbiakannya, memanfaatkannya, dan melestarikan. Salah satu contoh bentuk pembelajarannya yaitu pada materi pertumbuhan dan perkembangan kecambah, peserta didik diajarkan bagaimana cara menanamnya, menjaga, dan merawatnya hingga tumbuh dengan baik.

Penjelasan di atas sesuai dengan pendapat menurut (Kamelia et al., 2020: 42-47) Terdapat 3 langkah dalam pembelajaran berbasis alam, yaitu: 1) Perencanaan pembelajaran berbasis alam, dalam tahap perencanaan pembelajaran terdiri dari menetapkan tahap perkembangan peserta didik, menetapkan indikator, menyusun konsep materi pembelajaran, menentukan tema, menyususn rencana kegiatan program semester (PROMES), kegiatan mingguan (RPM), dan harian (RPPH) berbasis alam, menyiapkan sumber belajar dan alat peraga pembelajaran berbasis alam. 2) Pelaksanaan pembelajaran berbasis alam, dalam tahap ini pembelajaran berbasis alam dimulai dari penyambutan, pelaksanaan pijakan lingkungan, pijakan sebelum main, pijakan saat main, dan pijakan setelah main. Pelaksanaan pembelajarannya bisa di indoor ataupun outdoor. Pembelajaran diluar kelas dibuat senyata mungkin dengan melihat, mengamati dan berinteraksi dengan objek secara langsung, sehingga pembelajaran tersebut menjadi bermakna dan dapat memberi pengalaman nyata. Sedangkan yang indoor dengan memindahkan alat yang berhubungan dengan alam seperti batu, pasir, tanah, daun, dan lainnya kedalam kelas. Kemudian anak didik dibuat kelompok dan disuruh mengamati. 3) Evaluasi pembelajaran berbasis alam, dalam tahap ini dilakukan penilaian yang dilakukan guru bisa dengan 3 cara yaitu penilaian dengan pengamatan, catatan anekdot, dan portofolio. Penilaian dengan pengamatan yaitu guru mengamati untuk menilai aspek afektif atau tingkah laku anak. Selain itu tahap pelaksanaan BBA hampir sama dengan tahap pelaksanaan pendidikan karakter peduli lingkungan. Menurut Husnun \& Minsih (2017: 6), tahap pelaksanaan pendidikan karakter peduli lingkungan dimulai dari tahap perencanaan pembelajaran, kemudian tahap pelaksanaan pembelajaran, dan tahap evaluasi pembelajaran. Maka dapat disimpulkan, bahwa tahapan pembelajaran BBA di mulai dari tahap perenanaan, tahap pelaksanaan, dan tahap evaluasi. Berikut tabel hasil wawancara yang tekah dilakukan oleh peneliti.

Metode Belajar Bersama Alam (BBA) sebagai penerapan ekoliterasi di SD Muhammadiyah Alam Surya Mentari Surakarta

Setiap pembelajaran pasti memiliki tujuan yang berbeda-beda. Dari tujuan itu maka untuk mencapai tujuan caranya juga berbeda-beda, maka metodenya juga berbeda-beda. Untuk mencapai tujuan itu bisa menggunakan berbagai jenis metode, itu semuanya dipakai tergantung apa yang mau di tuju dari tujuan pembelajaran yang dibuat atau kegiatan pembelajaran yang akan dilakukan. Menurut Aditya (2016: 166) Metode adalah seperangkat langkah (apa yang harus dikerjakan) yang tersusun secara sistematis (urutannya logis). Metode pembelajaran dapat dianggap sebagai suatu prosedur atau proses yang teratur, suatu jalan atau cara yang teratur untuk melakukan kegiatan pembelajaran. Setiap materi pembelajaran tidak dapat menggunakan metode pembelajaran yang sama, oleh karena itu sebelum mengajar seorang guru harus memilih metode pembelajaran yang sesuai dengan materi oleh Lutvaidah (2015: 280).

Penjelasan diatas sesuai dengan pendapat dari Rahmatin, (2011: 17) bahwa kendala atau hambatan yang di alami dalam pelaksanaan Belajar Bersama Alam (BBA) diantaranya yaitu kondisi cuaca yang kurang baik, kurangnya pengawasan guru terhadap setiap peserta didik saat pembelajaran. Maka dari penjelasan diatas dapat disimpulkan bahwa kendala atau hambatan di dalam pelaksanaan BBA yaitu faktor lingkungan yang meliputi cuaca yang tidak menentu, mood peserta didik dalam 
mengikuti proses pembelajaran, pembelajaran membutuhkan waktu yang lama, dan pengawasan ekstra terhadap peserta didikm di saat berlangsungnya proses pembelajaran bersama alam.

Solusi terkait kendala di dalam pelaksanaan Belajar Bersama Alam (BBA) sebagai penerapan ekoliterasi di SD Muhammadiyah Alam Surya Mentari Surakarta

Pembelajaran yang dilaksanakan pada BBA berbasis aktivitas, maka membutuhkan waktu yang lama, untuk solusinya biasanya di sambung atau dilanjutkan di pertemuan berikutnya. Sedangkan untuk mengatasi mood peserta didik, biasanya guru selalu memberikan semangat dan sesuatu yang membuat anak didik itu tertarik untuk mempelajari lebih jauh dan lebih dalam, atau biasa kita buat anak-anak takjub terlebih dahulu, sehingga siswa penasaran dan tertarik. Kemudian untuk kendala terkait keterbatasan laboratorium alam yang tersedia di ruang lingkup sekolah, solusinya adalah guru akan menggunakan metode lain, misalkan menampilakan film atau video yang berkaitan dengan materi yang akan guru sampaikan atau meminta anak-anak membawa sesuatu yang akan di kaji lebih ulang bersama yang dimana di sekolah itu tidak ada, misalkan akan membedah buah melon, untuk mengetahui jenis biji terbuka dan tertutup, anak di minta untuk membawa macam-macam buah. Lebih banyak lagi ruang lingkup yang akan dibahas, akan lebih berkesan lagi di anak. Hal ini sesuai dengan pendapat (Ikhsan \& Ruslan, 2017: 2) bahwa dengan membawa siswa langsung ketempatnya siswa akan lebih memahami apa saja yang ada di lingkungan sekolah dan manfaat lingkungan sekolah. Siswa tidak hanya belajar dengan teori tetapi langsung melihat benda sekitar.

Peran guru di dalam pelaksanaan Belajar Bersama Alam (BBA) sebagai penerapan ekoliterasi di SD Muhammadiyah Alam Surya Mentari Surakarta

Beberapa peran guru seperti diatas sesuai dengan pendapat dari (Juhji, 2016: 54-60) bahwa peran guru diantaranya yaitu: a) Guru sebagai pendidik, peran guru sebagai pendidik adalah peran-peran yang berkaitan dengan tugas-tugas memberi bantuan dan dorongan (supporter), tugas-tugas pengawasan dan pembinaan (supervisor), serta tugas-tugas yang berkaitan dengan mendisiplinkan anak. b) Guru sebagai pengajar dan pembimbing, guru yang memberi pelajaran atau memberi materi. c) Guru sebagai pelatih dan penasihat, proses pendidikan dan pembelajaran memerlukan latihan keterampilan, baik intelektual maupun motoric, sehingga menuntut guru bertindak sebagai pelatih. d) Guru sebagai pembaharu (Inovator), guru menerjemahkan pengalaman yang telah lalu ke dalam kehidupan yang bermakna bagi peserta didik. e) Guru berperan sebagai pribadi, model, dan teladan, guru harus memiliki kepribadian yang mencerminkan seorang pendidik. f) Guru sebagai pembangkit pandangan (motivator) dan pendorong kreativitas, guru dituntut kreatif membangkitkan motivasi belajar peserta didik. g) Guru sebagai pekerja rutin dan aktor, guru bekerja dengan keterampilan dan kebiasaan tertentu. h) Guru sebagai pemindah kemah dan pembawa cerita, guru harus memahami hal yang bermanfaat dan tidak bermanfaat bagi peserta didik. i) Guru sebagai emansipator, pengawet dan kulminator. j) Guru sebagai peneliti dan evaluator. Selain pendapat diatas, menurut Minsih \& Galih (2018: 24-25) bahwa guru berperan sebagai pengelola kelas atau pengelola pengajaran, guru sebagai fasilitator, guru berperan sebagai motivator, guru sebagai demonstrator, guru sebagai mediator, dan guru sebagai evaluator.

\section{SIMPULAN}

Hasil penelitian berdasarkan uraian dan pembahasan di atas, menunjukkan Belajar Bersama Alam (BBA) adalah belajar tidak hanya belajar di alam, tetapi belajar memanfaatkan alam sekitar dengan cara menjaga, merawat alam, sehingga di dalam BBA berlangsung interaksi langsung dengan makhluk Tuhan bernama alam semesta serta media yang digunakan juga lebih banyak pada pemanfaatan alam sekitar. Ekoliterasi adalah peduli terhadap lingkungan hidup, bagaimana penyelamatan lingkungan hidup tidak hanya pada saat ini tetapi di masa yang akan datang, di masa yang lebih jauh lagi, ekoliterasi kaitannya pembelajaran yang melibatkan interaksi antara peserta didik dengan lingkungan, kegiatan pembelajaran dimana peserta didik dilatih untuk memanfaatkan alam dengan baik, serta peserta didik bisa mengetahui bagaimana merawat alam. 
Tahapan pelaksanaan Belajar Bersama Alam (BBA) sebagai penerapan ekoliterasi di SD Muhammadiyah Alam Surya Mentari Surakarta, tahapan pelaksanaannya, yaitu: 1) Tahap Perencanaan yaitu yang awalnya adalah pemetaan KI-KD ke dalam spyder web dan tema, kemudian kita buat weekly plan/rencana belajar selama satu pekan. Dan di dalam tahap ini guru menyusun Rencana Pelaksanaan Pembelajaran (RPP) yang mencerminkan pembelajaran berpusat pada siswa. 2) Tahap Pelaksanaan yaitu melaksanaan pembelajaran sesuai dengan Rencana Pelaksanaan Pembelajaran (RPP) yang telah disusun. Pelaksanaannya: pertama, peserta didik langsung terjun ke lapangan (luar kelas), yang dimaksud disisni yaitu terjun ke alam secara langsung. Kemudian mencari sumber belajar, yang dimaksud yaitu dari tujuan pembelajaran yang telah dibuat sebelumnya, kita cari sumber belajarnya langsung dari alam selama proses pembelajaran berlangsung. Selanjutnya bereksplorasi, artinya peserta didik dibiarkan untuk bereksplorasi dengan alam sekitar sesuai dengan materi yang diajarkan. Kemudian peserta didik menuliskan hasil dari eksplorasi alam sekitar yang sudah mereka lakukan. Setelah itu hasilnya dikumpulkan menjadi satu baru di analisis satu-satu secara bersama-sama dengan guru. 3) Tahap Evaluasi yaitu dilakukan selama proses pembelajaran. 4) Tahap Tindak Lanjut yaitu untuk mengembangkan proses pembelajaran yang lebih baik. Kendala atau hambatan yang di alami dalam pelaksanaan BBA yaitu faktor lingkungan yang meliputi cuaca yang tidak menentu, mood peserta didik dalam mengikuti proses pembelajaran, kemudia pembelajaran membutuhkan waktu yang lama, dan pengawasan ekstra terhadap peserta didik di saat berlangsungnya proses pembelajaran bersama alam.

\section{REFERENSI}

Aditya, D. Y. (2016). Pengaruh Penerapan Metode Pembelajaran Resitasi Terhadap Hasil Belajar Matematika Siswa. Jurnal SAP, 1(2), 165-174.

Ainiyah Nur. (2013). Pembentukan Karakter Melalui Pendidikan Agama Islam. Jurnal Al-Ulum, 13(1), 25-38.

Anggito, A., \& Setiawan, J. (2018). Metodologi Penelitian Kualitatif. CV Jejak.

Fatiihudin, D., \& Holisin, I. (2011). Cara Praktis Memabami Penulisan Karya Ilmiah, Artikel Ilmiah \& Hasil Penelitian Skripsi, Tesis, dan Disertasi. Unit Penerbit Dan Percetakan.

Hidayat, D. (2019). Penerapan Konsep Pendidikan Sekolah Alam Sebagai Upaya Mewujudkan Child Friendly School. The 9th University Research Colloquium.

Husnun, R. N., \& Minsih. (2017). Pendidikan Karakter Peduli Lingkungan Dalam Proses Pembelajaran di SD Alam Harapan Kita Kabupaten Klaten. Harapan Kita Kabupaten Klaten. Skripsi. Fakultas Keguruan Dan Ilmu Pendidikan, Universitas Mubammadiyah Surakarta, 6.

Ikhsan, A. S. S., \& Ruslan, R. (2017). Pemanfaatan Lingkungan Sekolah Sebagai Sumber Belajar Di Sd Negeri 2 Teunom Aceh Jaya. Jurnal Pendidikan Guru Sekolah Dasar, 2(1), 1-12.

Juhji. (2016). Peran Urgen Guru Dalam Pendidikan. Jurnal Ilmiah Bidang Kependidikan, 10(01), 52-62.

Kamelia, D., Nurillah, Siti Uzlifatul Jannah, \& Pratiwi, Y. W. (2020). Pengembangan Kurikulum PAUD Berbasis Alam. Islamic EduKids: Jurnal Pendidikan Anak Usia Dini, 02, 42-47.

Kulnieks. (2013). Eco-Literacy Development through a Framework for Indigenous and Environmental Educational Leadership. Canadian Journal of Environmental Education, 18, 111-125.

Lutvaidah, U. (2015). Pengaruh Metode Dan Pendekatan Pembelajaran Terhadap Penguasaan Konsep Matematika. Jurnal Formatif, 5(3), 279-285. 
M. Khusniati. (2012). Pendidikan Karakter Melalui Pembelajaran Ipa. Jurnal Pendidikan IPA Indonesia, Indonesian Journal of Science Education, 1(2), 206-207.

Minsih, \& Galih, A. (2018). Peran Guru Dalam Pengelolaan Kelas. Profesi Pnedidikan Dasar, 5(1), 20_ 27.

Nasution, M. K. (2017). Penggunaan Metode Pembelajaran Dalam Peningkatan Hasil Belajar Siswa. Jurna Ilmiah Bidang Pendidikan, 11(1), 9-16.

Noviana, E., Supentri, S., Hidayati, R., \& Huda, M. N. (2018). Why Do Students Need to Establish Ecoliteracy? Journal of Teaching and Learning in Elementary Education (Jtlee), 1(2), 69. https://doi.org/10.33578/jtlee.v1i2.5874

Putri, S. S., Japar, M., \& Bagaskorowati, R. (2019). Increasing ecoliteracy and student creativity in waste utilization. International Journal of Evaluation and Research in Education, 8(2), 255-264. https://doi.org/10.11591/ijere.v8i2.18901

Raco.J.R. (2010). Metode Penelitian Kualitatif. PT. Grasindo.

Rahmat, P. S. (2009). Penelitian Kualitatif. Journal Equilibrium, 5(9), 1-8.

Rahmatin, E. (2011). Model Pembelajaran Sekolah Alam Ungaran (SAUNG) Desa Lorog Kecamatan Ungaran Barat Kabupaten Semarang. Universitas Negeri Semarang.

Ritonga, H. I. (2020). Sababat Alam Bercerita "Kegiatan Belajar di Sekolah Alam." Guepedia The Fisrt On-PublisherIin Indonesia.

Rusmana \& Akbar. (2017). Pembelajaran Ekoliterasi Berbasis Proyek Di Sekolah Dasar. Jurnal Edukasi Sebelas April, 1(1), 1-12.

Sulthan, D. (2019). Penerapan Prinsip-Prinsip Arsitektur Ekologis Pada Desain Sekolah Alam Di Kota Bogor. Jurnal SENTHONG 2019, 2(1), 323-332.

Sunanik. (2018). Pembelajaran Berbasis Alam Untuk Anak Usia Dini Di Tk Alam Al Azhar Kutai Kartanegara. Jurnal Pendidikan Madrasah Ibtidaiyah, 3(Nomor 1), 81-110.

Yuliani, W., \& Supriyanto. (2019). Strategi Pembinaan Karakter Cinta Lingkungan Di Tk Alam Al Ghifari Blitar. Jurnal Mahasiswa, 7(1), 1-10. 